ISSN: $1979-4940$

E-ISSN: $2477-0124$
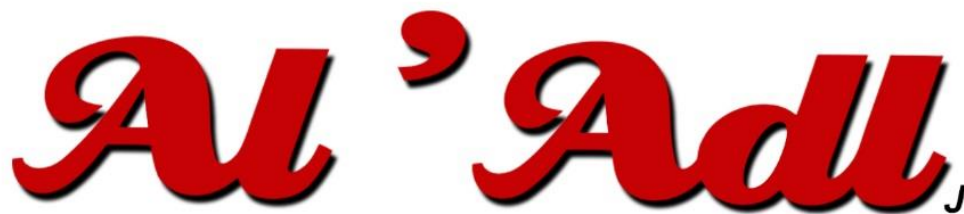

Jurnal Hukum

Editorial Office: Faculty of Law, Islamic University Of Kalimantan,

Jalan Adhyaksa No. 2 Kayutangi Banjarmasin, Kalimantan Selatan, Indonesia (70123)

Email: al_adl@uniska-bjm.ac.id

Web: http://ojs.uniska-bjm.ac.id

\section{ANALISIS KEAMANAN SIBER DAN HUKUM PIDANA DARI PERSPEKTIF GENDER DAN FILSAFAT POLITIK ALISON M. JAGGAR}

\author{
Alfonso Munte \\ Fakultas Sekolah Kajian Stratejik dan Global, Program Studi Kajian Gender \\ Universitas Indonesia \\ J1. Salemba Raya No.4, RW.5, Kenari, Kec. Senen, Kota Jakarta Pusat, DKI Jakarta
}

E-Mail : alfonso.munte@ui.ac.id $\begin{array}{ll}\text { Submitted } & : \text { 10 Maret } 2021 \\ \text { Revised } & : \text { 20 April } 2021 \\ \text { Accepted } & : \text { 30 April } 2021 \\ \text { Published } & : 1 \text { Mei } 2021\end{array}$

(C) Licence by CC BY-NC-SA

\begin{abstract}
The policy for increasing sensitivity, awareness, and problem solving for women, youth, and children has been in the works for a long time. This virtue in affirming the rights of women, youth, and children has made it a global issue. This grand idea has earned a stage in the community and institutions in the world. Unfortunately, in the negotiation process, they are weak and weakened. Often they do not get involves in the process of policies making and legislation especially in cybersecurity, the law of security, accessibility to cybersecurity, and the law. Therefore, based on the imbalance mentioned, the issue formulated, do the policymaker of cybersecurity law question the experience and identity of women in legal texts? How can this be possible? This article tries to analyze cybersecurity and legal struggles from Alison M. Jaggar's political philosophy and then analyzes dialectically with Feminist Legal Analysis to save women, adolescents, and children from exploitation in cyberspace. The method used in this research is a literature study. Based on the descriptive results of the data, I find that it is difficult until today for women to achieve justice in legal processes related to cyber violence.
\end{abstract}

Keywords: Alison M. Jaggar's Political Philosophy; Feminist Analysis of Law; Cybersecurity; Vulnerable Groups; Criminal Law.

\title{
Abstrak
}

Kebijakan membangun kepekaan, kesadaran dan pemecahan masalah perempuan, remaja dan anak telah lama dikerjakan sejak dahulu. Keutamaan ini dalam penegasan hak perempuan, remaja dan anak telah menjadikannya sebagai isu global. Kebajikan telah mendapatkan panggung dari komunitas dunia dan badan-badan dunia. Sayangnya, dalam proses negosiasi, mereka lemah dan dilemahkan. Seringkali mereka tidak mendapatkan tahapan dalam proses pembuatan kebijakan dan perundang-undangan khusus untuk keamanan siber, hukum keamanan, aksesibilitas ke dalam keamanan siber dan hukum. Oleh karena itu, berdasarkan ketidakseimbangan antara keamanan siber dan hukum kebebasan, saya mengajukan pertanyaan, apakah para perumus keamanan siber dan hukum legal mempertanyakan pengalaman dan identitas perempuan dalam teks-teks hukum? Bagaimana hal ini dapat dimungkinkan?. Artikel ini mencoba menganalisis keamanan siber dan perjuangan 
hukum dari filsafat politik Alison M. Jaggar kemudian menganalisis secara dialektis dengan Analisis Hukum Feminis bagaimana menyelamatkan perempuan, remaja dan anak-anak dari eksploitasi di dunia maya. Metodologi penelitian yang digunakan adalah studi pustaka. Berdasarkan hasil deskriptif pada data, saya menemukan perempuan sulit mencapai keadilan dalam proses hukum yang berhubungan dengan kekerasan siber hingga saat ini.

Kata kunci: Filsafat Politik Alison M. Jaggar, Analisis Hukum Feminis, Keamanan Siber, Kelompok Rentan, Hukum Criminal. 


\section{PENDAHULUAN}

Tulisan ini berangkat dari kegelisahan bahwa kelompok rentan (perempuan, remaja dan anak-anak) kerap lemah dan dilemahkan, kerap tidak mendapat panggung dalam proses pembuatan kebijakan dan legislasi secara khusus keamanan siber dan hukum pidana. Saya melihat kurangnya akses terhadap keamanan siber dan hukum pidana, tafsiran diskriminatif pada kaum rentan, serta politisasi frasa “manusia sama di hadapan hukum”.

Alin Teodorus Drăgan (2018) meneliti tentang penggunaan internet sebagai ladang aktivitas kriminal baru bagi para predator. Penelitian Drăgan yang berjudul "Child Pornography and Child Abuse in Cyberspace" menunjukkan,

"The Internet is a vulnerable system, and this aspect, combined with the advantages it offers (storage, processing and transmission of huge amounts of data, accessibility, ease of use, distance-independence, the possibility of applications in the business field), have resulted in a favourable context for criminal activities, triggering the emergence of a new criminal phenomenon - cybercrime."

Proses internet tentang aksesibilitas, transmisi data, jarak mandiri, penyimpanan data serta pemrosesan data menjadi sebuah ladang kepentingan bagi para kriminal. Penelitian Drăgan menelusuri tindak kriminal pada anak mengenai pornografi, khususnya mencari mangsa bagi pedofil.

Laurensius Arliman yang dekat dengan penelitian saya mengenai cyber bullying. Bedanya, Arliman menggunakan pendekatan hukum normatif. Pendekatan hukum normatif dikhususkan pada pendekatan statuta atau menelusuri aturan hukum yang berhubungan dengan Undang-Undang, Undang-Undang Nomor 11 Tahun 2008 tentang Informasi dan Transaksi Elektronik (UU ITE) dan KUHP. Sisi lain, Arliman menggunakan pendekatan koseptual perlindungan hukum itu sendiri terhadap anak sebagai korban. ${ }^{2}$ Sedangkan saya menggunakan pendekatan feminis legal teori disertai dengan filsafat politik Alison M. Jaggar. Alison M. Jaggar selain sosok filosof, dia juga merupakan sosok yang concern dengan isu-isu gender.

Selain itu, saya menemui penelitian Fenomena tersebut membuat saya mencoba mendekatkan diri kepada pendekatan teori hukum feminis atau Feminist Legal Theory (FLT) untuk membuka ruang agar kelompok rentan diberdayakan, mendapat panggung dan ikut

\footnotetext{
${ }^{1}$ Drăgan, A. T. (2018). Child Pornography and Child Abuse in Cyberspace. Journal of Legal Studies, 21(35), 52-60. doi:http://dx.doi.org/10.1515/jles-2018-0004.

${ }^{2}$ Laurensius, S., Danel Situngkir, Putri Rianda, and Fauzi Rahmat. Cyber Bullying against Children in Indonesia. Padang: European Alliance for Innovation (EAI), 2018.
} 
serta berpartisipasi dalam proses pembuatan kebijakan. Khususnya, hubungan keamanan siber dan hukum pidana kepada akses perempuan rentan secara proporsional dalam produk-produk hukum. Tujuannya, membangun argumentasi dalam perumusan dan implementasi hukum dalam rangka advokasi kesetaraan. Hal ini berhubungan, seperti Kelly (2008) dalam bukunya Alison M. Jaggar “Just Methods: An Interdisciplinary Feminist Reader” mengatakan,

"Throughout historical time, women have been largely excluded from making war, wealth, laws, governments, art, and science. Men, functioning in their capacity as historians, considered exactly those activities constitutive of civilization.. Women figured chiefly as exceptions, those who were said to be as ruthless as, or wrote like, or had the brains of men." 3

Teori legal feminis berangkat dari kritik dengan menggugat prinsip netralitas dan objektivitas yang diagungkan oleh sarjana hukum arus utama, yaitu tentang adagium equality before law. ${ }^{4}$ Ketidaknetralan dan ketidak-objektifan hukum dalam perumusannya menempatkan perempuan, remaja dan anak sebagai korban hukum positif. Hal ini disebabkan, menurut Sulistyowati, bahwa hukum adalah hasil tawar menawar dan kompromi politik. ${ }^{5}$ Artinya, produk hukum dalam perumusannya, seolah terpolitisasi oleh kepentingan golongan tertentu. Pada posisi ini, perumus produk hukum yang berotoritas, atau yang berkuasa menjadi representasi hukum itu sendiri.

\section{RUMUSAN MASALAH}

Rumusan masalah yang saya ajukan adalah mencoba menelusuri faktor ketimpangan dalam produk hukum itu sendiri. Misalnya, Undang-Undang yang mengatur Sistem Peradilan Pidana Terpadu (SPPT) terhadap Anak pada tahun 2012. Minimnya Aparat Penegak Hukum (APH) yang responsif gender. Khususnya APH yang berhubungan langsung dengan perempuan dan anak pada Sistem Peradilan Pidana Terpadu atau disingkat SPPT. ${ }^{6}$ Frasa Justice for all juga mengalami masalahnya sendiri ketika ketiadaan perbedaan laki-laki dan perempuan di mata hukum. Perempuan memiliki perbedaan dengan laki-laki dalam hal sistem reproduksi. Sistem reproduksi mempunyai andil penting ketika masuk dalam dunia kekerasan. Selain sistem reproduksi, pembuat kebijakan produk hukum kerap didominasi oleh laki-laki

${ }^{3}$ Gadol Kelly Joan, "The Social Relation of the Sexes: Methodological Implications of Women's History" dalam Alison M Jaggar, "Just Methods: An Interdisciplinary Feminist Reader" (United State: Paradigm Publisher, 2008).

${ }^{4}$ Sulistyowati Irianto, "Perempuan dan Hukum: Menuju Hukum yang Berperspektif Kesetaraan dan Keadilan," (Jakarta: Yayasan Pustaka Obor Indonesia, 2019).

${ }^{5}$ Ibid., 74.

6 "Bappenas," online: (https://www.bappenas.go.id/files/7014/0850/2296/BUKU_-_BS_RPJMN_KG__UPDATE_9_AGUST_2014.pdf). 
yang, tentu punya kepentingan di dalamnya sebagai cerminan politik. Perempuan, remaja dan anak merupakan kelompok rentan dengan kekerasan. Kekerasan kepada kelompok rentan tersebut terwujud dengan sikap enggan berbicara di ruang publik mengenai pelecehan di dunia maya saat berjumpa dengan rekan terdekat, pihak aparat, atau sosok yang dipercayai. Hal ini disebabkan adanya rasa malu dan ketakutan dalam diri sendiri. Melihat gap yang tak kunjung selesai hingga kini, saya menelusuri beberapa informasi deskriptif baik dari media online maupun dari penelitian sebelumnya yang mengkonfirmasi bahwa perempuan menjadi the second class dalam hukum itu sendiri. Maka rumusan masalah dalam penelitian saya adalah sebagai berikut:

1) Apakah perumus keamanan siber dan hukum pidana memperhitungkan pengalaman dan jati diri perempuan rentan dalam teks-teks hukum?

2) Sejauh mana hukum pidana memperhitungkan pengalaman dan jati diri perempuan rentan dalam teks-teks hukum?

\section{METODE PENELITIAN}

Metode penelitian yang saya gunakan dalam penulisan artikel ini adalah metode kepustakaan dengan teknik analisa teori legal feminis dan filsafat politik Alison M. Jaggar. Metode kepustakaan menurut Catherine (2016) yang berjudul, "Writing a Literature Review" bahwa kajian pustaka (literature review) merupakan penempatan temuan penelitian dalam konteks penelitian sebelumnya melalui buku dan/atau jurnal dengan cara mengevaluasi, mengumpulkan dan menyortir kemudian meringkas bahan yang relevan dengan penelitian. ${ }^{7}$ Tujuan metode kepustakaan menurut Western Sydney University Library (2016), "The purpose of a literature review is to gain an understanding of the existing research and debates relevant to a particular topic or area of study, and to present that knowledge in the form of a written report." 8

Artinya, saya berusaha mendapatkan pemahaman penelitian-penelitian terdahulu yang relevan (dekat) dengan penelitian saya mengenai sajian informasi yang bersumber dari buku-buku dan berbagai jurnal.

\footnotetext{
${ }^{7}$ Catherine L Winchester and Mark Salji, "Writing a Literature Review," Journal of Clinical Urology 2016, Vol. 9 (5) 308-312.

"Literature | Weviews Western Sydney University," online: (https://westernsydney.edu.au/studysmart/home/assessment_guides/literature_reviews).
} 


\section{PEMBAHASAN}

Saya mencoba menganalisis keamanan dunia maya dan hukum pidana dari perspektif gender, sekaligus bagaimana cara menyelamatkan perempuan, remaja dan anak-anak dari eksploitasi dunia maya. Keadilan bagi semua atau Justice for all melalui pendekatan feminist legal theory telah menjadi masalah ketika diletakkan setara antara laki-laki dan perempuan karena pada dasarnya laki-laki telah menerima privilege dalam beragam hal. Sehingga, jika ingin meletakkan dalam posisi setara, perempuan terlebih dahulu perlu mendapatkan kebebasannya dan pemberdayaan.

\section{A. Riwayat dan Teori Filsafat Politik Alison M.Jaggar.}

Alison Mary Jaggar atau sering disingkat dengan Alison M. Jaggar adalah seorang filsuf feminis Amerika. Alison lahir di Inggris pada tanggal 23 September 1942. Perempuan yang pernah menjabat di Departemen Filsafat, Universitas Colorado di Boulder sebagai Direktur Pascasarjana dan Ketua Asosiasi (2004-2008) tersebut menyelesaikan B.A. Hons., M. Litt., dan Ph.D bidang filsafat di University of London (Bedford College) pada tahun 19611964. University of Edinburgh tahun 1965-1967 untuk program Magister dan di State University of New York di Buffalo pada tahun 1967-1970 untuk program Doktor Filsafat. ${ }^{9}$

Setelah lulus menyelesaikan satu degree, Mary (1942) langsung melanjutkan kuliahnya di 3 universitas yang berbeda. Menurut saya, ini merupakan prestasi gemilang seorang scholar dalam kepakaran dalam hal filsafat sosial, filsafat politik, dan etika. Universitas Colorado fakultas filsafat mengkonfirmasi bahwa saat ini Alison bekerja sebagai Professor Emerita, College Professor of Distinction. Sepuluh tahun terakhir, Jaggar memperkenalkan gender sebagai kategori analisis mengenai dialektika filosofis keadilan global. Dia pernah menjadi peneliti multidisiplin yang fokus meneliti tema kemiskinan global dan pendekatan naturalisasi terhadap epistemologi moral dalam konteks ketidaksetaraan dan perbedaan budaya untuk menangani perselisihan moral. ${ }^{10}$

Alison Mary Jaggar (1983) dalam bukunya Feminist Politics and Human Nature bagian 1, Feminist as Political Philosophy mengatakan,

".. there are conceptual connections between oppression and liberation, on the one hand, and the traditional political ideals of freedom and justice, on the other. To speak of

\footnotetext{
9"Alison Jaggar Philosophy University of Colorado Boulder," (https://www.colorado.edu/philosophy/people/emeriti/alison-jaggar).

$10 "$ Ibid.
} 
oppression and liberation, however, is not simply to introduce new words for old ideas... not just a new political terminology but a new perspective on political phenomena."

Alison melihat bahwa terdapat hubungan konseptual antara pembebasan dan penindasan. Lebih lanjut Alison mengatakan bahwa satu sisi berupa cita-cita mengenai kebebasan politik tradisional. Sedangkan, di sisi lain adalah keadilan. Jaggar berangkat dari perspektif kebebasan dan penindasan. Jaggar berpendapat bahwa secara prinsip, kebebasan (liberation) bukanlah situasi pencapaian final. Melainkan, proses eliminasi bentuk-bentuk penindasan sejauh penindasan semakin bertumbuh. ${ }^{11}$

Jaggar menggunakan kata kunci penindasan (oppression) dalam teorinya. Dia mempertanyakan,

“... what is the precise nature of women's special oppression? Does the nature of their oppression vary for different groups of women? can individual women ascape oppression? if women are oppressed, who are their oppressors? can one be an unknowing or unintentional oppressor? may oppressors themselves be oppressed." 12

Alison Mary Jaggar mempertanyakan sifat penindasan. Perempuan pada dasarnya adalah objek yang tertindas. Teori-teori feminis lain, termasuk Alison Mary Jaggar lebih meletakkan bahwa perempuan adalah sosok yang teropresi, termarjinalkan, tersisihkan dalam ruang domestik, ruang publik, reproduksi tubuh maupun reproduksi sosial. Perempuan kerap kehilangan suara (voiceless) baik di ranah domestik maupun publik. Rintangan akses kerap didera perempuan saat ingin berekspresi mengenai keutuhan dirinya, otonomi tubuhnya, dan, bahkan otoritas tubuh dan kehidupannya. Selain itu, Jaggar juga mempertanyakan siapa sebenarnya penindas (secara sadar ataupun tidak), apakah perempuan pemangku kebijakan, dengan kebijakan yang tidak berpihak kepada perempuan atau perempuan pada umumnya. Mary memilah kedua golongan perempuan tersebut. Jaggar menawarkan bahwa perempuan sebagai individu mampu mengatasi penindasan meskipun telah masuk dalam lingkaran penindasan.

\section{B. Perempuan, Remaja dan Anak-Anak dalam Hukum}

Perempuan, remaja dan anak-anak merupakan subjek yang kerap mendapat predikat sebagai korban hukum positif. Perempuan diasosiasikan pada golongan kelompok rentan.

\footnotetext{
1983), hlm. 6.

${ }^{11}$ Alison Mary Jaggar, "Feminist Politics and Human Nature" (USA: Rowman \& Allanheld Publisher, ${ }^{12}$ Ibid, hlm. 7.
} 
Identitas kaum rentan yang saya maksudkan disini, mengutip pendapat Irianto (2019) berasal dari kelas, agama, etnik, ras, dan bangsa yang berbeda. ${ }^{13}$ Berdasarkan data statistik Patroli Cyber, saya menemukan tren kejahatan siber 5 tahun sebelumnya di Indonesia (Januari 2015 s.d Januari 2019), bahwa total angka kejahatan mengalami peningkatan dari tahun ke tahun. Sedangkan, jumlah kasus laporan yang telah selesai oleh Subbagbinops Ditreskrimsus seluruh Polda, hanya setengah dari total kejahatan tiap tahun. Total aduan sejumlah 1.455 sedangkan kerugian mencapai 49,59 juta rupiah. Menurut Patroli Cyber, Total Platform Terlapor (TPT) diambil dari aplikasi Instagram, Whatsapp, dan Facebook. Hasil laporan Patroli Cyber menunjukkan bahwa wilayah persebaran konten negatif paling banyak berada di wilayah Jawa Barat, kedua Jawa Timur. Laporan selanjutnya menunjukkan dalam kategori umur pelapor di dominasi oleh umur 21 hingga 25 tahun, 26 hingga 30, dan 17 hingga 20 tahun. Berdasarkan statistik antara laki-laki dan perempuan, jumlah pelapor lebih banyak atau didominasi oleh laki-laki-dengan jumlah 762 orang-dibandingkan dengan perempuan dengan jumlah 640 orang. Selanjutnya, hasil laporan Patroli Cyber menemukan bahwa pekerjaan pelapor paling banyak berasal dari kalangan BUMN, sedangkan petani, nelayan menempati angka paling rendah. $^{14}$

Artinya, 5 tahun terakhir, setiap tahun jumlah total kejahatan siber mengalami peningkatan sedangkan kasus terselesaikan hanya setengah dari keseluruhan. Ini menandakan bahwa perkembangan internet tidak hanya membawa dampak positif, namun juga membawa dampak negatif. Berdasarkan platform terlapor, platform media sosial yang paling banyak digunakan oleh pengguna internet setiap waktu adalah Instagram.

Berdasarkan situs Statistika, Indonesia merupakan negara kelima pengguna internet terbesar di dunia selain China, India, US dan Brazil dengan jumlah 143,27 juta orang pada Maret 2019. ${ }^{15}$ Databooks menambahkan bahwa Indonesia merupakan peringkat kelima dalam jumlah pengguna internet pada bulan Maret tahun 2019. ${ }^{16}$ Menurut saya, Indonesia masuk ke dalam jajaran pengguna internet paling rajin setiap harinya dalam mengakses ragam informasi (termasuk ekploitasi kaum rentan [dhi: perempuan, remaja dan anak]).

${ }^{13}$ Sulistyowati Irianto, "Perempuan dan Hukum: Menuju Hukum yang Berperspektif Kesetaraan dan Keadilan," (Jakarta: Yayasan Pustaka Obor Indonesia, 2006), hlm. 75.

14 "Patroli Siber," online: (https://patrolisiber.id/statistic).

${ }^{15}$ Statistika, "Number of Internet Users in Selected Countries," online: (https://www.statista.com/statistics/262966/number-of-internet-users-in-selected-countries/).

${ }^{16}$ Databoks, "Indonesia Peringkat Kelima Dunia dalam Jumlah Pengguna Internet," online: (https://databoks.katadata.co.id/datapublish/2019/09/11/indonesia-peringkat-kelima-dunia-dalam-jumlahpengguna-internet). 
Triantoro Safaria meneliti remaja Yogyakarta dengan judul Prevalence and Impact of Cyberbullying in a Sample of Indonesian Junior High School Students dalam dalam beberapa periode tahun terakhir yang dituangkan dalam abstraknya mengatakan bahwa cyberbullying telah menyebar luas ke seluruh sekolah menengah pertama. Hasilnya, remaja terkena dampak cybervictimization dalam jumlah besar. Triantoro kemudian mengaitkan Cybervictimization dengan hasil kesehatan psikologis dengan tanda negatif. Tujuan penelitian Triantoro untuk menguji dampak dan prevalensi cybervictimization sampel siswa sekolah menengah pertama di Yogyakarta, Indonesia. Triantoro mengambil sampel atau contoh sejumlah 102 orang. Tujuh siswa kelas melibatkan diri melalui penelitian dan menemukan, “72 (70,6\%) anak laki-laki dan $30(29,4 \%)$ anak perempuan menjadi korban kekerasan siber atau cybervictimization." Triantoro menemukan bahwa mayoritas atau sejumlah $80 \%$ siswa setiap harinya me(di)laporkan diri karena mengalami kekerasan siber/cybervictimization. Hasil penelitian Triantoro menunjukkan adanya hubungan positif antara cybervictimization dan tingkat tekanan psikologis siswa. Artinya, terdapat hubungan cybervictimization dengan tingkat tekanan psikologis siswa di SMP Yogyakarta. ${ }^{17}$

Selain fakta-fakta di atas, faktor lain yang menyebabkan kaum rentan mengalami kekerasan siber yaitu sikap enggan berbicara di ruang publik mengenai pelecehan di dunia digital kepada pihak aparat, teman dekat, orangtua atau sosok seseorang yang dapat dipercayai. Penyebabnya, adalah rasa malu dan ketakutan pada kaum rentan itu sendiri. Mereka takut 'aib' dan kebiasaan buruknya terbongkar ke jagat media sosial. Media sosial merupakan media tercepat dalam menyebarkan informasi. Media sosial beroperasi dalam rentang waktu singkat dengan tidak terlalu memperdulikan persebaran konten. Oleh karena itu, konten negatif maupun konten positif sebagai komoditas atau konsumsi publik mengiring pengguna sosial media pada ragam tafsir terhadap suatu konten viral.

Saya mencoba menelusuri faktor ketimpangan dalam produk hukum itu sendiri. Misalnya, Undang-Undang yang mengatur Sistem Peradilan Pidana Terpadu (SPPT) terhadap Anak pada tahun 2012. ${ }^{18}$ Minimnya Aparat Penegak Hukum (APH) yang responsif gender.

\footnotetext{
${ }^{17}$ Triantoro Safaria, "Prevalence and Impact of Cyberbullying in a Sample of Indonesian Junior High School Students," The Turkish Online Journal of Educational Technology, 2016, 82, Volume 15 issue 1 January.

18 "Bappenas," online: (https://www.bappenas.go.id/files/7014/0850/2296/BUKU_-_BS_RPJMN_KG__UPDATE_9_AGUST_2014.pdf).
} 
Khusunya APH yang berhubungan langsung dengan perempuan dan anak pada Sistem Peradilan Pidana Terpadu (SPPT). ${ }^{19}$

Berdasarkan data deskriptif singkat mengenai produk hukum di atas, perumus kebijakan mampu mengakomodasi keamanan siber dan merumuskan kembali hukum pidana yang mampu mengakomodasi kaum rentan. Kemudian perlunya menambah APH yang sadar atau sensitif gender. APH mampu melihat siapa yang dirugikan dalam produk hukum.

Berdasarkan gambaran keresahan yang muncul akhir-akhir ini maka akademisi hukum yang berperspektif feminis serta para aktivis mengajukan draft RUU PKS ${ }^{20}$ yang hingga saat ini belum ada tanda-tanda masuk ke Prolegnas 2021 agar dipertimbangkan menjadi bagian dari produk hukum untuk mengakomodasi perempuan, remaja dan anak, kaum marjinal/penyintas tersebut, untuk memperoleh hak-hak kesamaan manfaat dalam keadilan hukum.

Draft RUU PKS membahas tentang kekerasan seksual. Kekerasan seksual—dalam penjabaran RUU PKS — adalah setiap perbuatan merendahkan, menghina, menyerang tubuh, hasrat seksual seseorang (saya menambahkan; dhi: kaum rentan), dan fungsi reproduksi secara paksa, bertentangan dengan kehendak penyintas yang menyebabkan kaum rentan tidak mampu memberikan persetujuan (concent) dalam perasaan bebas. Hal ini disebabkan adanya ketimpangan relasi kuasa yang berakibat pada penderitaan atau kesengsaraan secara fisik, psikis, seksual, kerugian secara ekonomi, sosial, budaya, dan/atau politik." 21

Selain itu, menurut New Detik, draft RUU PKS dapat dijadikan sebagai alat untuk mengkritisi argumen fraksi Partai Keadilan Sejahtera terkait penolakannya terhadap draft RUU PKS yang tidak berpihak kepada korban. ${ }^{22}$ Padahal, Draft RUU PKS bertujuan untuk mengakomodasi, memberikan akses, dan memperjuangkan hak-hak keadilan perempuan sekaligus memberi ruang untuk mengedukasi masyarakat tentang kekerasan seksual, termasuk kekerasan seksual dalam ranah digital.

Berdasarkan penelusuran saya, Bappenas merupakan lembaga penting negara untuk mempercepat persoalan analisis hukum yang peka gender atau yang berpihak pada fenomena hukum bagi kaum rentan, termasuk kaum rentan yang menjadi korban dalam dunia siber. Terdapat berbagai persoalan dalam perundang-undangan yakni, ketidakharmonisan substansi

\footnotetext{
${ }^{19}$ Ibid..

${ }^{20}$ Draft Rancangan Undang-Undang PKS, http://dpr.go.id/doksileg/proses2/RJ2-20170201-0431283029.pdf

${ }^{21}$ Ersa Khaiya, Polemik RUU PKS dan Perlunya Nalar Kritis," online: (https://news.detik.com/kolom/d4415917/polemik-ruu-pks-dan-perlunya-nalar-kritis).

${ }^{22}$ Ibid.
} 
antar undang-undang yang terjadi dalam proses perumusan kebijakan dan peraturan, implementasi produk hukum maupun upaya penegakan hukum. ${ }^{23}$

Persoalan ini dapat ditemukan melalui pemantau terkait minimnya mekanisme proses penyelidikan dan penyidikan oleh sebagian polisi pada unit UPPA yang belum responsif gender. Contohnya, adanya stereotip dari polisi dengan mengkriminalisasi korban. ${ }^{24}$ Penelusuran Bappenas selanjutnya bahwa sebagian hakim dalam proses peradilan pada kasus kekerasan terhadap perempuan (perkosaan dan eksploitasi) belum responsif gender. Hasil terakhir, masih ditemuinya petugas Bapas dan Lapas yang berkaitan masalah kesehatan reproduksi belum responsif gender. ${ }^{25}$

Chris Reed (2018) melakukan penelitian berjudul, "Why judges need jurisprudence in cyberspace" yang berfokus tentang dilema hakim dalam memutuskan perkara yang terjadi di dunia maya (cyber). Reed mengatakan bahwa hakim memerlukan yurisprudensi dalam dunia maya saat memutuskan apakah menggunakan hukum nasional (national law) jika pelakunya dari negara lain, atau pendekatan eksternal bagi pengguna dunia maya, yakni, hukum akan berotoritas pada kasus dunia maya dengan mempersuasif pelaku dunia maya agar klaim menjadi sah. $^{26}$ Reed menelusuri kinerja hakim jika "pasien" nya berasal dari negara/tempat lain yang melakukan tindak kejahatan virtual. Saya menelusuri penelitian, pada akhirnya melihat bahwa pelaku kejahatan dalam dunia maya (termasuk dari luar negeri) tidak mempunyai efek jera jika hukum mengenai cyber pun lemah dan tak menjerat pelaku. Padahal, berdasarkan hidangan data menunjukkan bahwa perempuan dan anak kerap dirugikan dalam bermedia sosial dan dalam waktu yang sama, jerat hukum bagi pelaku cyber crime pun kurang memuaskan korban.

Menurut Catatan Tahunan 2019 oleh Komnas Perempuan, yang saya kutip dari safenet.or.id mengatakan bahwa jenis kasus kekerasan terhadap perempuan dalam dunia siber mengalami peningkatan. Sepanjang tahun 2018, ada 97 aduan kasus kekerasan terhadap perempuan di dunia siber dengan 125 jenis kekerasan siber. Tahun sebelumnya terdapat 65

${ }^{23}$ Berdasarkan Pembangunan Kesetaraan Gender Background Study RPJMN III (2015-2019) dalam

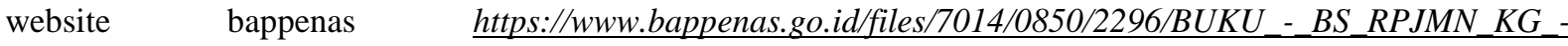
_UPDATE_9_AGUST_2014.pdf,

24 "Bappenas," online: (https://www.bappenas.go.id/files/7014/0850/2296/BUKU_-_BS_RPJMN_KG__UPDATE_9_AGUST_2014.pdf).

${ }_{25}$ Ibid.

${ }^{26}$ Reed, C. (2018). Why judges need jurisprudence in cyberspace. Legal Studies, 38(2), 263-278. doi:http://dx.doi.org/10.1017/lst.2017.15 
aduan kasus dengan 95 jenis kekerasan siber. ${ }^{27}$ Catatan Komnas Perempuan mengatakan kondisi ini semakin miris bila memperhatikan pelakunya didominasi orang-orang terdekat (61\%), "pacar, mantan pacar, suami, atau mantan suami. Sementara sisanya dilakukan oleh orang lain, mulai dari teman, kenalan, bahkan orang yang tidak dikenal."28

Catatan laporan Komnas Perempuan, CNN Indonesia, Rabu, 30/01/2019 03:31 WIB, mengkonfirmasi dari sumber yang sama, bahwa "Enam puluh lima laporan kasus kekerasan perempuan di dunia maya yakni melakukan pendekatan untuk menipu (cyber-grooming), pelecehan online (cyber harassment), dan peretasan (hacking)." 29 menambahkan, "Terdapat kasus konten ilegal (illegal content), pelanggaran privasi (infringement of privacy), ancaman distribusi foto atau video pribadi (malicious distribution), pencemaran nama baik (online defamation), dan rekrutmen online (online recruitment)., ${ }^{30}$

Salah satu contohnya adalah kasus Baiq Nuril: Perempuan yang dipidanakan karena merekam percakapan mesum akan 'tagih amnesti' ke Jokowi. ${ }^{31}$ Baiq Nuril tetap dihukum enam bulan penjara dan dengan denda sebesar 500 juta rupiah setelah dijerat dengan UndangUndang Informasi dan Transaksi Elektronik (ITE) mengenai pendistribusian atau mentransmisikan content kesusilaan yang tertera dalam pasal 27 ayat 1 ITE walaupun eksekusi hukuman tersebut ditunda oleh kejaksaan dan, saat ini perempuan asal Nusa Tenggara Barat tersebut masih bebas. ${ }^{32}$

Bimo Fundrika dari Divisi Digital At-Risk menurut penuturan safenet.or.id, mencontohkan bahwa kasus perekaman percakapan merupakan contoh penegakan hukum yang belum berpihak pada korban. Safenet juga mencantumkan tautan panduan memahami dan menyikapi KBGO (Kekerasan Berbasis Gender Online) dalam s.id/panduanKBGO. Ketidakberpihakan ini ditandai dengan alpanya perlindungan korban pada kekerasan sehingga korban dijadikan tersangka.

CNN Indonesia, SAFEnet menginformasikan pada Rabu, 30/01/2019 03:31 WIB bahwa jumlah korban KBGO atau Kekerasan Berbasis Gender Online mengalami lonjakan,

27 Safenet, "Kampanye Safenet untuk 16 Hari Anti Kekerasan terhadap Perempuan," online: (https://id.safenet.or.id/2019/11/awaskbgo-kampanye-safenet-untuk-16-hari-anti-kekerasan-terhadapperempuan/).

${ }^{28}$ Ibid.

${ }^{29} \mathrm{CNN}$ Indonesia, "Maraknya Kekerasan terhadap Perempuan di Dunia Maya," online: (https://www.cnnindonesia.com/teknologi/20190129185350-185-364845/maraknya-kekerasan-terhadapperempuan-di-dunia-maya).

${ }^{30}$ Ibid.

${ }^{31}$ Kasus Baiq Nuril: Perempuan yang dipidanakan karena merekam percakapan mesum akan 'tagih amnesti' ke Jokowi - BBC News Indonesia," online: (https://www.bbc.com/indonesia/indonesia-48878086).

${ }^{32}$ Ibid. 
kemudian meminta APH untuk menindak tegas pelaku, memperhatikan kasus secara kontekstual, dan tidak membuat korban menjadi korban yang kedua kali dalam proses peradilan. ${ }^{33}$ Artinya, perlunya masyarakat untuk menghormati hak-hak digital sesama pengguna internet; hak atas aman bagi perempuan, kaum rentan (remaja dan anak-anak). ${ }^{34}$

\section{Munculnya Teori Hukum Feminis}

Teori hukum feminis beranjak dari hubungan antara hukum dan perempuan. Hubungan tersebut tergantung apakah hubungan yang malah jauh dari akses, partisipasi hukum atau malah menjadi sarana untuk mendapatkan akses dan pemberdayaan. Saya mencoba mengambil satu dari sekian teori hukum feminis dan menetapkan diri pada teori hukum feminis Martha Albertson Fineman (1970).

Teori hukum feminis atau Feminist Legal Theory (FLT), teori yang muncul pada tahun 1970-an. Pada tahun 1970-an, teori FLT muncul bersamaan dengan Critical Legal Studies (CLS) yang berusaha menerobos diskriminasi postulat Justice for all atau keadilan untuk semua. Semua (all) menurut postulat tersebut adalah satu atau tiadanya perbedaan lakilaki dan perempuan. Padahal secara biologis, perempuan punya sistem reproduksi biologis yang beda. Belum lagi dibedakan sistem reproduksi sosialnya. Perbedaan tersebut menunjukkan bahwa hukum adalah cerminan filosofis politik yang dominan. ${ }^{35}$ Hal ini ditegaskan juga oleh Synott (2003) bahwa karena laki-lakilah yang menulis hukum sehingga ia perlu memasukkan kepentingan-kepentingannya dengan sejumlah cara dan dalam setiap disiplin ilmu. ${ }^{36}$ Baik Savitri maupun Synnott sama-sama mengatakan akibat dari justice for all maka Teori hukum Feminis menjadi teori yang penting.

Cara berpikir teori hukum feminis yang diadopsi oleh Savitri, Savitri melalui buku Martha Chamallas, "Introduction to Feminist Legal Theory", menyebutkan lima cara berpikir teori hukum feminis antara lain; pengalaman perempuan; adanya bias gender secara implisit; jeratan ganda dan dilema dari perbedaan; reproduksi model dominasi laki-laki dan membuka pilihan-pilihan perempuan. Dengan demikian, Niken menambahkan bahwa penalaran hukum feminis tidak menyetujui adanya monolithic community yang kerap

33 CNN Indonesia, "Maraknya Kekerasan terhadap Perempuan di Dunia Maya," online: (https://www.cnnindonesia.com/teknologi/20190129185350-185-364845/maraknya-kekerasan-terhadapperempuan-di-dunia-maya).

${ }^{34}$ Ibid.

35 A Synnott, "Tubuh Sosial: Simbolisme Diri dan Masyarakat," (Yogyakarta: Jalasutra Sulastri, 2003) Dikutip dalam Niken, "Perempuan dan Hukum: Menuju Hukum yang Berperspektif Kesetaraan dan Keadilan," Diedit oleh Sulistyowati Irianto, (Jakarta: Yayasan Pustaka Obor Indonesia, 2006).

${ }^{36}$ Ibid. 
digunakan oleh laki-laki dalam penalaran ranah praksis. ${ }^{37}$ Lebih lanjut, dengan pengertian yang sama, Bartlett mengkonfirmasi kesadaran feminis dengan mengatakan,

"Feminist consciousness raising creates knowledge by exploring common experiences and patterns that emerges from shared tellings of life event. What were experienced as personal hurts individually suffered reveal themselves as a collective experience of oppression.." ${ }^{38}$

Bartlett mengatakan dalam pengertian tambahan bahwa peningkatan kesadaran feminis menciptakan pengetahuan dengan mengeksplorasi pengalaman dan pola umum yang muncul dari berbagi pengalaman hidup. Apa yang dialami sebagai luka pribadi yang diderita secara individu mengungkapkan diri mereka sebagai pengalaman penindasan kolektif.

Martha Albertson Fineman, sosok perempuan yang menjadi salah satu tokoh teori hukum feminis, dalam tiap karyanya, Martha berani untuk menantang lembaga dan struktur untuk menjelaskan penderitaan perempuan setiap hari. Martha menantang konsep keluarga yang netral gender, asumsi tentang tenaga kerja, operasi institusi, dan bahkan lebih lagi, negara itu sendiri. Martha meminta pertanggungjawaban negara atas kegagalan dan stagnasi. Keberanian tersebut, menurut saya mempunyai dasar pengalaman. Pengalamannya membimbing generasi dan sejumlah sarjana feminis. ${ }^{39}$

Penelitian empiris, Janine M. Zweig, Meredith Dank, Jennifer Yahner dan Pamela Lachman yang berjudul Tingkat Penyalahgunaan Kencan Cyber Di Antara Remaja dan keterkaitannya dengan Bentuk-Bentuk Kekerasan Lain dalam Kencan Remaja mengatakan bahwa remaja menyalahgunakan teknologi untuk menyalahgunakan dan mengendalikan pasangan kencan. Menurut penelitian Janine $d k k$., Lebih dari seperempat pemuda dalam hubungan saat ini mengalami beberapa bentuk korban pelecehan kencan siber pada tahun sebelumnya. ${ }^{40}$ Korban menurut penelitian Janine $d k k$., tidak hanya laki-laki. Perempuan turut ambil bagian di dalamnya sebagai korban. Namun, menurut penelitian Janine $d k k$., perempuan melaporkan bahwa tingkat kekerasan siber yang dialami perempuan lebih besar dari pelanggaran cyber dating abuse non-seksual dari laki-laki. Responden yang melaporkan sedang berhubungan dengan berkencan, berada dalam hubungan kencan di masa lalu

37 Niken, "Perempuan dan Hukum: Menuju Hukum yang Berperspektif Kesetaraan dan Keadilan," Diedit oleh Sulistyowati Irianto, (Jakarta: Yayasan Pustaka Obor Indonesia, 2006), hlm. 42.

${ }^{38}$ Katharine T Bartlet, "Feminist Legal Method," dalam "Feminist Legal Theory Foundation," edited by D. Kelly Weisberg, (Temple University: Press, 1993).

${ }^{39}$ Martha Chamallas, "Introduction to Feminist Legal Theory," Second Edition, (Aspen Publisher). Hal 1143.

${ }^{40}$ Tanine et al., "Rate of Cyber Dating Abuse Among Teens and How It Relates to Other Forms Teen Dating Violence," Youth Adolescence, Vol. 42:2013, 1065. 
(hubungan yang dimaksud adalah kekerasan seksual hingga bentuk psikologis dan emosional. $^{41}$

Penelitian Muhammad Hatta $d k k$., yang berjudul, "Upaya Mengatasi Tindak Kejahatan Siber di Indonesia" mengenai dampak negatif menjadi seorang kriminal siber yang mengatakan bahwa seseorang dapat dengan mudah menjadi penjahat hanya dengan membuat program, aplikasi, akun, blog, dan situs di berbagai media massa dan media sosial untuk melakukan penipuan, data pencurian, penyebaran konten pornografi, radikalisme, penggunaan ilegal kartu kredit, pidato kebencian, perjudian online, pelacuran online pelacuran terorisme dan sebagainya. Untuk mengatasi kejahatan di ruang dunia maya pemerintah telah mengeluarkan Undang-Undang Nomor 19 Tahun 2016 tentang Perubahan atas UndangUndang Nomor 11 Tahun 2008 tentang Informasi dan Transaksi Elektronik. ${ }^{42}$ Namun, dalam penelitian ini, menurut saya, hanya sebatas penjabaran deskriptif mengenai dampak negatif dari internet itu sendiri.

Penelitian di atas, sama hal nya dengan penelitian yang dilakukan oleh Himawan yang berjudul, "Indonesia: hate speech yang mendominasi kejahatan siber Indonesia pada tahun 2016" yang mengatakan bahwa hate speech menjadi kejahatan siber online yang paling sering dilaporkan ke polisi. Menurut Jakarta Post Online pada hari Minggu, Himawan mengatakan pidato kebencian, terutama tentang agama dan ras, adalah kejahatan internet yang paling sering dilaporkan. Himawan menambahkan bahwa kasus termasuk pelecehan, fitnah, pencemaran nama baik, provokasi dan ancaman terhadap individu atau kelompok. Lebih lanjut Himawan mengatakan bahwa penggunaan ucapan kebencian yang meluas dibantu oleh aplikasi pesan yaitu percakapan whatsapp. Sehingga polisi menutup beberapa akun media sosial yang mendistribusikan tipuan sebagai tanggapan terhadap kasus dan akan lebih responsif dalam menangani laporan dari publik. ${ }^{43}$

Kedua artikel di atas masih tergolong netral gender. Netral gender yang ditandai dengan ketiadaan informasi mengenai, mengapa perempuan, remaja, dan anak-anak menjadi korban kriminal siber. Selain itu, tiadanya informasi sejauh mana pengawasan dan implementasi penegakan hukum Undang-Undang Nomor 19 Tahun 2016 mengenai perubahan atas Undang-Undang Nomor 11 Tahun 2008 tentang Informasi dan Transaksi Elektronik

${ }^{41}$ Tanine et al., "Rate of Cyber Dating Abuse Among Teens and How It Relates to Other Forms Teen Dating Violence," Youth Adolescence, Vol. 42:2013, 1063-1077.

${ }^{42}$ Muhammad Hatta et al J, “Journal of Physics: Conference Series.” (2018) Phys .: Conf, Ser. 1114 012081, 2018.

${ }^{43}$ Himawan, "Indonesia: Hate Speech Dominates Indonesia's Cyber Crime in 2016," (Bangkok: Asia News Monitor, 2017). 
(ITE). Saya melihat bahwa pertanyaan tentang mengapa agama dan ras menjadi kejahatan internet dan siapa yang paling dirugikan secara implisit tidak ada penjelasan lebih lanjut dalam penelitian terdahulu di atas.

Saya tertarik melihat penelitian dari Anastasia Powell dan Nicola Henry yang berjudul, "Policing technology-facilitated sexual violence against adult victims: police and service sector perspectives," mengenai teknologi yang difasilitasi TFSV untuk memeriksa respons polisi terhadap bahaya yang timbul akibat kekerasan seksual digital dengan mengidentifikasi: pelecehan berbasis gender dan seksualitas, pelecehan seksual online, cyberstalking, penggunaan teknologi komunikasi, dan image-based sexual exploitation (termasuk revenge pornography). Penelitian ini dilakukan dengan metode wawancara sebanyak 30 responden pemangku kepentingan dengan polisi, layanan hukum dan penyedia sektor layanan kekerasan dalam rumah tangga. ${ }^{44}$ Meskipun hanya berupa wawancara dalam kemasan observasi kepada 30 responden, menurut saya - meskipun dilakukan dengan metode penelitian in-depth interview dengan sedikit responden - terdapat titik terang bagi polisi dan penyedia sektor layanan kekerasan untuk meng-upgrade dan update dirinya agar menjadi penegak hukum yang responsif gender.

Jaggar, filosof feminis, dalam tulisannya, "Gender and Global Justice" menanggapi secara filosofis di balik kekerasan terhadap perempuan sehingga pengalaman perempuan sebagai objek, terus dilanggengkan. Pertama, ignoring them. Kedua, treating them instrumentally. Ketiga, treating them as natural. Keempat, blaming them on non-western cultures. Kelima, blaming the victims. ${ }^{45}$ Tanggapan filosofis tersebut konteksnya mengenai perempuan di dunia kerja dengan reproduksi sosialnya. Namun, kelima pelanggengan kekerasan dibalik tanggapan filosofis tersebut menurut saya menjadi penting mengapa perempuan, khususnya di dunia cyber mendapat kekerasan.

Hal yang sama dengan permasalahan filosofis menurut penelitian Setyowati dkk., terkait dengan penghapusan KDRT melihat bahwa terdapat permasalahan filosofis dalam melihat Undang-Undang penghapusan KDRT hanya berlaku pada tataran ontologis, yaitu permasalahan biologis itu sendiri menekankan sanksi secara epistemologis yang retributif

\footnotetext{
${ }^{44}$ Anastasia Powell and Nicola Henry, "Policing Technology-Facilitated Sexual Violence Against Adult Victims: Police And Service Sector Perspectives," Policing And Society. Vol. 28 No. 3, 2018:291-307.

${ }_{45}$ Alison M Jaggar, et.al., "Gender and Global Justice," (Cambridge UK: Polity Press, 2014), hlm. 2022.
} 
kepada tersangka pelaku KDRT. ${ }^{46}$ Seharusnya, menurut Setyowati dkk., UU kekerasan dalam rumah tangga melihat dengan titik pandang ideologis, yaitu melihat KDRT sebagai persoalan kematangan emosi, mental dan spiritual (ketiga hal ini masuk pada ranah ontologi). Sehingga pemulihan (pada ranah epistemologi), melihat kebenaran secara utuh melalui persoalan kematangan emosi tersebut. ${ }^{47}$ Saya melihat-walaupun subjek penelitiannya mengenai KDRT-penelitian Setyowati dkk., mempunyai kemiripan mengenai paradigma hukum pidana melihat perempuan sebagai korban secara koherensi. Koherensi dengan tidak melihat hukum yang berperspektif gender yang berkonsekuensi pada peninggalan cara pandang bahwa manusia_-baik laki-laki maupun perempuan—sama di hadapan hukum.

Titik pijak Jaggar adalah keadilan distributif. Bagaimana keadilan dapat didistribusikan bukan hanya kepada pembuat hukum yang notabenenya adalah laki-laki yang mempunyai kecenderungan bahwa produk hukum lebih kepada political interest. Tetapi juga kepada perempuan dengan pertimbangan pengalaman, akses, stereotype yang berkembang pada perempuan itu sendiri. Filosof perempuan tersebut menegaskan bahwa, "Central to justice is the idea of moral balance." 48 Jaggar mempertanyakan, dimana dan kapan tuntutan moral keadilan berlaku. Siapa yang menjadi entitas subjek keadilan. Kategori atau jenis keadilan apa yang harus didistribusikan dengan cara adil, lalu akhirnya bagaimana. ${ }^{49}$ Pertanyaan tentang keadilan, bukan saja menuntut tentang jawaban atas pertanyaan tersebut, tetapi juga menjelaskan mengapa mendukung jawaban baik oleh hakim maupun pendukung teori legal feminis. ${ }^{50}$

\section{PENUTUP}

Menurut saya, perumus kebijakan perempuan seharusnya mengambil bagian dalam proses proses pembuatan kebijakan dan legislasi mengenai perangkat hukum. Perlunya memperhatikan perempuan, remaja dan anak sebagai subjek yang setara dengan memperhatikan serta menjunjung hak-hak digital perempuan remaja dan anak-anak pengguna internet yaitu hak atas aman bagi kaum rentan. Produk hukum sebenarnya sudah banyak,

${ }^{46}$ Setyowati, Dewi, and Emmilia Rusdiana. "Relevance of Criminal Law Formulation in the Law of Domestic Violence Elimination in Indonesia." [In English]. Journal of Indonesian Legal Studies 5, no. 1 (May 20202020-10-05 2020): 95-124. https://doi.org/http://dx.doi.org/10.15294/jils.v5i1.35362. https://search.proquest.com/scholarly-journals/relevance-criminal-law-formulation domestic/docview/2447003259/se-2?accountid=17242.

${ }^{47}$ Setyowati, Ibid.

48 Jaggar, Ibid., 1.

${ }^{49}$ Jaggar, Ibid., 2. 
hanya yang menjadi kendala (berdasarkan penelitian-penelitian sebelumnya) adalah tentang implementasi hukum bagi penegak hukum (hakim, aparat, maupun penjaga tahanan) sehingga wajah hukum menjadi ramah bagi perempuan, remaja dan anak-anak. Penegak hukum juga perlu mempertimbangkan historisitas perempuan, remaja dan anak sebagai korban yang harus dilindungi karena kejahatan siber dan historisitas tersebut terwujud hingga pada akar rumput dan hingga putusan pengadilan.

Tepatlah apa yang dipertanyakan Alison M. Jaggar bahwa perempuan yang mengalami penindasan (opressions) berhak mendapatkan kebebasan (freedom) dalam keutuhan dirinya sebagai-bukan hanya situasi pencapaian final, "In a sense, feminism has always exixted. Certainly, as long as women have been subordinated, they have resisted that subordination. Sometimes the resistance has been collective and conscious; at the other times it has been solitary and only half-concious, as when women have sough escape from their socially prescribed roles through illness, drug and alcohol, and even madness."

Tetapi, mendapatkan keadilan dalam perangkat-perangkat hukum yang membebaninya. Perempuan, remaja, anak-anak juga sama, sebagai sosok penyintas perlu mendapatkan perlindungan hukum, secara khusus perlindungan hukum yang berhubungan dengan dunia maya. Sebab, saya melihat bahwa sejauh ini masih minim sekali perlindungan hukum bagi perempuan, remaja dan anak-anak yang terjerat dalam ancaman, tubuh yang dieksploitasi di dunia maya dan persoalan-persoalan lain terkait siber. Saat ini, para aktivis dan akademisi sedang memperjuangkan RUU PK-S masuk ke dalam prolegnas 2021. Semoga harapan dan cita-cita para aktivis dan akademisi terwujud demi berlangsungnya kehidupan setara.

${ }^{51}$ Alison Mary Jaggar, "Feminist Politics and Human Nature," (USA: Rowman \& Allanheld Publisher, 1983), hlm. 3. 


\section{Buku}

\section{DAFTAR PUSTAKA}

Bartlet, Katharine T. 1993. "Feminist Legal Method," dalam "Feminist Legal Theory Foundation." edited by D. Kelly Weisberg, Temple University Press.

Chamallas, Martha. Introduction to Feminist Legal Theory. Second Edition. Aspen Publisher.

Himawan. 2017. Indonesia: Hate Speech Dominates Indonesia's Cyber Crime in 2016. Asia News Monitor. Bangkok.

Jaggar, Alison Mary. 1983. Feminist Politics and Human Nature. Rowman \& Allanheld Publisher. USA.

Jaggar, Alison M. et.al. 2014. Gender and Global Justice. Cambridge UK. Polity Press.

Kelly Joan, Gadol. The Social Relation of the Sexes: Methodological Implications of Women's History dalam Jaggar, Alison M. 2008. Just Methods: An Interdisciplinary Feminist Reader. United State: Paradigm Publisher.

Synnott, A. 2003. Tubuh Sosial: Simbolisme Diri dan Masyarakat. Jalasutra. Sulastri. Yogyakarta. Dikutip dalam Niken. 2006 Perempuan dan Hukum: Menuju Hukum yang Berperspektif Kesetaraan dan Keadilan. Diedit oleh Sulistyowati Irianto. Yayasan Pustaka Obor Indonesia. Jakarta.

\section{Jurnal}

Drăgan, Alin Teodorus. (2018). Child Pornography and Child Abuse in Cyberspace. Journal of Legal Studies, 21(35), 52-60. doi:http://dx.doi.org/10.1515/jles-2018-0004.

Hatta, Muhammad J . et al. 2018. "Upaya Mengatasi Tindak Kejahatan Siber di Indonesia Journal of Physics: Conference Series” Phys.: Conf, Ser. 1114012081.

Laurensius, S., Situngkir, D., Rianda, P., \& Rahmat, F. (2018). Cyber Bullying Against Children in Indonesia. In. Padang: European Alliance for Innovation (EAI).

Muhammad Hatta et al J. 2018. "Journal of Physics: Conference Series.” (2018) Phys .: Conf, Ser. 1114012081.

Powell, Anastasia and Nicola Henry. 2018. "Policing Technology-Facilitated Sexual Violence Against Adult Victims: Police And Service Sector Perspectives" POLICING AND SOCIETY. Vol. 28 No. 3.

Reed, C. (2018). Why judges need jurisprudence in cyberspace. Legal Studies, 38(2), 263278. doi:http://dx.doi.org/10.1017/lst.2017.15

Safaria, Triantoro. 2016. "Prevalence and Impact of Cyberbullying in a Sample of Indonesian Junior High School Students." The Turkish Online Journal of Educational Technology. Volume 15 issue 1-January.

Setyowati, D., \& Rusdiana, E. (2020). Relevance of Criminal Law Formulation in the Law of Domestic Violence Elimination in Indonesia. Journal of Indonesian Legal Studies, 5(1), 95-124. doi:http://dx.doi.org/10.15294/jils.v5i1.35362 
Tanine dkk. 2013. "Rate of Cyber Dating Abuse Among Teens and How It Relates to Other Forms Teen Dating Violence" Youth Adolescence. Vol. 42.

Winchester, Catherine L and Mark Salji, "Writing a Literature Review," Journal of Clinical Urology 2016, Vol. 9 (5) 308-312.

\section{Internet}

Alison Jaggar Philosophy University of Colorado Boulder. https://www.colorado.edu/philosophy/people/emeriti/alison-jaggar. (accessed on Februar 13th, 2021).

CNN Indonesia. 2019. Maraknya Kekerasan terhadap Perempuan di Dunia Maya. https://www.cnnindonesia.com/teknologi/20190129185350-185-

364845/maraknya-kekerasan-terhadap-perempuan-di-dunia-maya. (accessed on Desember $25^{\text {th }}, 2019$ ).

Curriculum vitae of. 2021. https://www.colorado.edu/philosophy/sites/default/files/attachedfiles/cv_jaggar.pdf. (accessed on Februar 13th, 2021).

Databoks. 2019. Indonesia Peringkat Kelima Dunia dalam Jumlah Pengguna Internet. https://databoks.katadata.co.id/datapublish/2019/09/11/indonesia-peringkatkelima-dunia-dalam-jumlah-pengguna-internet . (accessed on Desember $29^{\text {th }}$, 2019).

KBR. 2019. Mendorong Diakhirinya Kekerasan Berbasis Gender Online. https://kbr.id/intermezzo/02-

2019/mendorong_diakhirinya_kekerasan_berbasis_gender_online/98801.html. (accessed on Desember $27^{\text {th }}, 2019$ ).

Khaiya, Ersa. 2019. Polemik RUU PKS dan Perlunya Nalar Kritis. https://news.detik.com/kolom/d-4415917/polemik-ruu-pks-dan-perlunya-nalarkritis. (accessed on Desember $31^{\text {th }}, 2019$ ).

Ibrahim, Gibran Maulana. 2019. Ini Sederet Alasan F-PKS Tolak RUU Penghapusan Kekerasan Seksual. https://news.detik.com/berita/d-4417286/ini-sederet-alasan-fpks-tolak-ruu-penghapusan-kekerasan-seksual. (accessed on Desember $29^{\text {th }}$, 2019).

Patroli Siber. 2019. https://patrolisiber.id/statistic. (accessed on December $29^{\text {th }} 2019$ ).

Safenet. 2019. Kampanye Safenet untuk 16 Hari Anti Kekerasan terhadap Perempuan. https://id.safenet.or.id/2019/11/awaskbgo-kampanye-safenet-untuk-16-hari-antikekerasan-terhadap-perempuan/. (accessed on Desember $27^{\text {th }} 2019$ ).

Statistika. 2019. Number of Internet Users in Selected Countries. https://www.statista.com/statistics/262966/number-of-internet-users-in-selectedcountries/. (accessed on December $29^{\text {th, }} 2019$ ).

Western Sydney University Library. (2016). Essay purpose. Retrieved from https://westernsydney.edu.au/studysmart/home/assignment_help/writing. (accessed on April 27 ${ }^{\text {th, }}$ 2021). 
